\title{
Analytical Assessment of Bio- and Toxic Elements Distribution in Pu-erh and Fruit Teas in View of Chemometric Approach
}

\author{
Justyna Brzezicha-Cirocka $^{1} \cdot$ Malgorzata Grembecka $^{1} \cdot$ Piotr Szefer $^{1}$
}

Received: 11 January 2016 / Accepted: 13 March 2016/Published online: 2 April 2016

(C) The Author(s) 2016. This article is published with open access at Springerlink.com

\begin{abstract}
This study concerns application of flame atomic absorption spectrometry (FAAS) in assessment of macroand microelement and toxic metal levels $(\mathrm{Mg}, \mathrm{Ca}, \mathrm{K}, \mathrm{Na}$, $\mathrm{Mn}, \mathrm{Cu}, \mathrm{Fe}, \mathrm{Zn}, \mathrm{Cr}, \mathrm{Ni}, \mathrm{Co}, \mathrm{Cd}$ and $\mathrm{Pb}$ ) in dark (Pu-erh) and fruit tea leaves and their infusions. Phosphorus was also determined in the form of phosphomolybdate by spectrophotometric method. The reliability of the method was checked using three certified reference materials. The results of analysis were in agreement with the certified values, with analytical recovery ranging from 86 to $113 \%$. Significant correlations $(p<0.001)$ were found between concentrations of $\mathrm{P}, \mathrm{Zn}, \mathrm{K}, \mathrm{Ni}, \mathrm{Fe}, \mathrm{Co}$, $\mathrm{Cr}$, and $\mathrm{Pb}$ in $\mathrm{Pu}$-erh tea, whereas in fruit tea, such interdependences were found between $\mathrm{Mg}, \mathrm{Fe}, \mathrm{P}, \mathrm{Ni}$, and Co. Kruskal-Wallis test results have related differences in Pu-erh tea quality as well as technological processing of fruit tea to their mineral composition. In order to characterize tea elemental content, chemometric techniques such as factor analysis (FA) and cluster analysis (CA) were used. Their application allowed on differentiation of samples in view of the fermentation type, technological processing, and overall quality.
\end{abstract}

Keywords Tea $\cdot$ RDA $\cdot$ PTWI $\cdot$ FAAS $\cdot$ Factor analysis

Piotr Szefer

pszef@gumed.edu.pl

1 Department of Food Sciences, Medical University of Gdańsk, Al. Gen. J. Hallera 107, 80-416 Gdańsk, Poland

\author{
Abbreviations \\ CTC (crush, tear, curl), rollers during the manufacturing \\ of tea \\ CA Cluster analysis \\ FA Factor analysis \\ FAAS Flame atomic absorption spectrometry \\ PTWI Provisional tolerable weekly intake \\ RDA Recommended dietary allowance \\ RSD Relative standard deviation \\ SD Standard deviation
}

\section{Introduction}

There are approximately 1500 different varieties of tea, which can be grouped by taste and color [1]. The quality of tea depends mainly on the conditions of cultivation, the soil in which it grows, and numerous meteorological conditions. In general, teas are classified into four major types according to the manufacturing process. Among them, there can be listed non-fermented green and white teas, produced by drying and steaming fresh tea leaves. Second group constitutes semifermented oolong tea, obtained by a partial fermentation of fresh leaves before drying. Next, fully fermented black and dark teas are produced by a post-harvest fresh leaf fermentation stage before drying and steaming. There is also a postfermented tea (Pu-erh tea) that undergoes secondary fermentation and oxidation in an open air [1].

$\mathrm{Pu}$-erh refers to the tea plant (Camellia sinensis var. assamica (L.) O. Kuntze; Theaceae) native to the Upper Mekong River Region of China's Yunnan Province [2] and contiguous parts of China, Laos, Vietnam, Myanmar, and India [3]. Pu-erh tea is considered to be one of the most aromatic teas that have spicy taste and specific smell. Fine-leaved dark tea, Pu-erh from China, which is particularly well known, 
goes further fermentation and aging. It can be stored up to 50 years [4] and is used by some consumers as a medicine, tonic, beverage, source of energy, and well-being. Additionally, Pu-erh is valued for nutritive values, aiding digestion, strengthening of the immune system, and obesity prevention [3].

Today, consumers choose not only pure green, black, or dark tea but also that with various types of additives such as fruits. Fruit teas, which are conventionally named as such, should be called a mixture of dried fruits with or without $C$. sinensis leaves. There can be added any fruit, but the most common are apples, lychees, apricots, peaches, berries, and citrus. What is more, there are countries which have a particular favorite kind of fruit added to tea, i.e., dragon fruits are frequently added in South East Asia; in France, black currants; in the USA, pears; and in the Caribbean, mango puree [5].

Tea has numerous beneficial effects on health, such as prevention of low-density lipoprotein oxidation, decreased risk of cardiovascular diseases, and cancers [6, 7]. However, tea contains some undesirable trace elements (heavy metal ions) and organic compounds, such as oxalate. The main sources of heavy metals in tea such as $\mathrm{Pb}$ and $\mathrm{Cd}$ are fertilizers and local environmental factors [8]. Chen et al. [9] reported that $\mathrm{Pb}$ availability increased significantly as the soil $\mathrm{pH}$ decreased. Lead enters human body mainly through oral ingestion and absorption through the gut. The absorbed $\mathrm{Pb}$ is transferred to soft tissues, including a liver and kidneys, and to bone tissues, where it is accumulated with age. Cadmium's route of exposure is also through oral ingestion with the diet, and its absorption ranges from 1 to $10 \%$ for adults. The level of $\mathrm{Cd}$ in blood is used as an indicator of both recent and cumulative exposures, whereas urinary $\mathrm{Cd}$ predominantly reflects cumulative exposure and its concentrations in kidneys [10].

The aim of this study was to assess mineral nutrients and toxic metals levels in 32 kinds of Pu-erh and fruit teas including their infusions. There were also estimated health benefits and hazard associated with this tea consumption in view of permissible dietary limits. Due to the application of chemometric techniques, it was also possible to differentiate quantitatively mineral composition of tea samples and classify them according to the type of fermentation and technological processing.

\section{Materials and Methods}

\section{Samples}

The analyzed tea samples, both in loose form and tea bags, were bought in local markets and tea shops in Poland. The characteristics of dark (Pu-erh) and fruit tea species are summarized in Table 1. Both kinds of tea were analyzed for their content of potassium $(\mathrm{K})$, sodium $(\mathrm{Na})$, calcium $(\mathrm{Ca})$, magnesium $(\mathrm{Mg})$, manganese $(\mathrm{Mn})$, zinc $(\mathrm{Zn})$, copper $(\mathrm{Cu})$, iron $(\mathrm{Fe})$, phosphorus $(\mathrm{P})$, cobalt $(\mathrm{Co})$, nickel $(\mathrm{Ni})$, chromium $(\mathrm{Cr})$, cadmium $(\mathrm{Cd})$, and lead $(\mathrm{Pb})$. In total, 32 types of teas, ca. 300 analytical samples of leaves, and their infusions were analyzed. Blank samples were tested with each series of samples within the same conditions and using the same reagents.

\section{Preparation of Samples}

Tea leaves were homogenized using mill IKA ${ }^{\circledR}$ A11 Basic. About $10.0 \mathrm{~g}( \pm 0.0001 \mathrm{~g})$ of homogenized products portions was weighed and transferred to quartz crucibles. Tea samples were ashed in an electric furnace using a gradient of temperature up to $540{ }^{\circ} \mathrm{C}$. Mineralization procedure was based on the addition of $1.50 \mathrm{~mL} 36 \% \mathrm{HCl}$ (Tracepure ${ }^{\circledR}$, Merck, Darmstadt, Germany) and 2-3 drops of $63 \% \mathrm{HNO}_{3}$ (Tracepure $囚$, Merck, Darmstadt, Germany) to the ashes and evaporation to dryness on a boiling water bath. The dry residue was rewetted with $1.50 \mathrm{~mL}$ of $36 \% \mathrm{HCl}$ and heated for $1 \mathrm{~min}$, covered with a watch glass. Next, the watch glass was rinsed with ultra-pure water $\left(18 \mathrm{M} \Omega \mathrm{cm}^{-1}\right)$ from Milli-Q® system (Millipore Corp., Bedford, MA, USA) above the crucible, and the resulting solution was transferred to $25-\mathrm{mL}$ flasks.

In case of infusions, $2.0 \mathrm{~g} \mathrm{(} \pm 0.0001 \mathrm{~g})$ of materials (tea leaves) was weighed and transferred to a $250-\mathrm{mL}$ beaker. Then, tea brew was prepared with $200 \mathrm{~mL}$ of water and infused for $5 \mathrm{~min}$ under the watch glass cover. Subsequently, the solution was filtered through fluted paper filter and the resulting filtrate was transferred to a quartz crucible. Then, tea infusions were evaporated to dryness on a boiling water bath. The dry residue was ashed in a furnace, following the same procedure as with the dry sample [11].

\section{Elements Analyses}

The concentrations of elements ( $\mathrm{Mg}, \mathrm{Ca}, \mathrm{K}, \mathrm{Na}, \mathrm{Mn}, \mathrm{Cu}, \mathrm{Fe}$, $\mathrm{Zn}, \mathrm{Cr}, \mathrm{Ni}, \mathrm{Co}, \mathrm{Cd}$, and $\mathrm{Pb}$ ) were determined by atomic absorption spectrometry with an air-acetylene flame (FAAS) using the deuterium background correction. FAAS conditions are described in Table 2. The analysis was performed using Thermo Scientifics i3000. In case of $\mathrm{Na}$ and K, cesium chloride was added (cesium chloride, Merck, Darmstadt, Germany, $0.2 \% w / v$ ), which acts as an ionization buffer that shifts the equilibrium of ion reaction resulting in the free atomic form of the analyzed element. Magnesium and $\mathrm{Ca}$ were analyzed with the addition of $0.4 \% \mathrm{w} / v$ lanthanum oxide (lanthanum (III) oxide, Merck, Darmstadt, Germany), which is a correction buffer that connects permanently with the matrix instead of the analyzed element. Phosphorus was determined in the form of phosphomolybdate by spectrophotometric method [12] using UV-VIS spectrophotometer (Spekol 11, Carl Zeiss, Jena, Germany). 
Table 1 Characteristics of the analyzed products

\begin{tabular}{lll}
\hline No. Pu-erh tea & Producer & $\begin{array}{l}\text { Country/manufacturer's } \\
\text { declaration }\end{array}$ \\
\hline
\end{tabular}

\begin{tabular}{cl}
\hline Loose form of tea \\
1. & Pu-erh grapefruit-orange \\
2. & Pu-erh Tangela \\
3. & Pu-erh Royal \\
4. & Pu-erh warming punch \\
5. & Pu-erh Yunnan \\
6. & Pu-erh Superior \\
7. & Pu-erh \\
8. & Pu-erh cranberry \\
9. & Pu-erh peach \\
10. & Pu-erh strawberry \\
11. & Pu-erh cherries in rum \\
12. & Pu-erh \\
Tea bags & \\
13. & Pu-erh \\
14. & Tea Pu-erh \\
15. & Tea Spa \\
16. & Pu-erh tea \\
17. & Pu-erh and grapefruit \\
& Fruit tea \\
\hline &
\end{tabular}

Black tea with fruit

\begin{tabular}{clll} 
18. & Intensive Earl Grey and raspberry & Tetley & Bags \\
19. & Citrus fruits & Lipton & Bags \\
20. & Forest fruits & Lipton & Bags \\
21. & Lemon & Lipton & Bags \\
22. & Intensive Earl Grey and lemon & Tetley & Bags \\
23. & Lemon and lime & Dilmah & Bags \\
24. & Raspberry & Dilmah & Bags \\
25. & Black lemon & Teekanne & Bags \\
Fruit tea & & & \\
26. & Berries & Vitax Family & Bags \\
27. & Raspberry & Teekanne & Bags \\
28. & Fresh orange & Teekanne & Bags \\
29. & Tea garden raspberry & Herbapol & Bags \\
30. & Tea garden & Herbapol & Bags \\
31. & Cranberry & Saga & Bags \\
32. & Cherry & Saga & Bags \\
\hline
\end{tabular}

\section{Accuracy of the Analytical Method Used for Quantification}

The reliability of the method was checked using three certified reference materials (Tea, NCS ZC73014, Oriental Basma Tobacco Leaves INCT-OBTL-5 and Polish Virginia Tobacco Leaves INCT-PVTL-6). Digestion of these materials was performed with the same decomposition procedure used for tea samples. The recoveries of the studied elements ranged between 86 and $103 \%$, and the relative standard deviations (RSDs) of the test material were $0.11-14.3 \%$ for Tea, NCS ZC73014. Tobacco INCT-OBTL-5 and INCT-PVTL-6 characterized with recoveries in the range of $87-113 \%$ and RSDs between 0.02 and $10.3 \%$. All the bioelement and toxic metal measurement results in reference materials are summarized in Table 3.

\section{Sensitivity}

Limits of detection (LODs) of the method applied for macroelements, $\mathrm{Ca}, \mathrm{P}, \mathrm{Mg}, \mathrm{K}$, and $\mathrm{Na}$, were as follows: 0.02 , 
Table 2 Experimental conditions for element determination by FAAS

\begin{tabular}{lllllll}
\hline Element & $\begin{array}{l}\text { Wavelength } \\
(\mathrm{nm})\end{array}$ & $\begin{array}{l}\text { Slit } \\
(\mathrm{nm})\end{array}$ & $\begin{array}{l}\text { Fuel flow } \\
(\mathrm{L} / \mathrm{min})\end{array}$ & $\begin{array}{l}\text { Burner width } \\
(\mathrm{mm})\end{array}$ & $\begin{array}{l}\text { Lamp current } \\
(\mathrm{mA})\end{array}$ & $\begin{array}{l}\text { Deuterium background } \\
\text { correction }\end{array}$ \\
\hline $\mathrm{Ca}$ & 422.7 & 0.5 & 1.0 & 9.5 & 6 & - \\
$\mathrm{K}$ & 766.5 & 0.5 & 0.8 & 6.4 & 8 & - \\
$\mathrm{Mg}$ & 285.2 & 0.5 & 0.8 & 6.5 & 6 & + \\
$\mathrm{Na}$ & 589.0 & 0.2 & 0.8 & 6.3 & 8 & - \\
$\mathrm{Mn}$ & 279.5 & 0.2 & 1.0 & 7.3 & 12 & + \\
$\mathrm{Fe}$ & 248.3 & 0.2 & 1.0 & 7.5 & 15 & + \\
$\mathrm{Zn}$ & 213.9 & 0.2 & 0.8 & 6.4 & 10 & + \\
$\mathrm{Cu}$ & 324.8 & 0.5 & 0.8 & 7.3 & 5 & + \\
$\mathrm{Cr}$ & 357.9 & 0.5 & 1.2 & 11.4 & 5 & + \\
$\mathrm{Ni}$ & 232.0 & 0.1 & 0.9 & 7.5 & 5 & + \\
$\mathrm{Pb}$ & 217.0 & 0.5 & 1.0 & 7.5 & 10 & + \\
$\mathrm{Cd}$ & 288.8 & 0.5 & 0.8 & 7.5 & 8 & + \\
$\mathrm{Co}$ & 240.7 & 0.2 & 0.8 & 7.3 & 15 & + \\
\hline
\end{tabular}

0.03, 0.02, 0.04, and $0.02 \mathrm{mg} / 100 \mathrm{~g}$, respectively. LODs for microelements, $\mathrm{Cu}, \mathrm{Cr}, \mathrm{Zn}, \mathrm{Mn}, \mathrm{Fe}, \mathrm{Ni}$, and $\mathrm{Co}$, in the analyzed samples were as follows: 0.009, 0.001, 0.02, 0.02, 0.01, 0.002 and $0.003 \mathrm{mg} / 100 \mathrm{~g}$, respectively. LODs for toxic elements $\mathrm{Pb}$ and $\mathrm{Cd}$ amounted to 0.004 and $0.003 \mathrm{mg} / 100 \mathrm{~g}$, respectively. The limits of quantification (LOQs) were defined as LOQ $=3$. LOD and were equal to $0.06,0.09,0.06,0.12$, and $0.06 \mathrm{mg} /$ $100 \mathrm{~g}$ for the analyzed macroelements, i.e., $\mathrm{Ca}, \mathrm{P}, \mathrm{Mg}, \mathrm{K}$, and $\mathrm{Na}$, respectively. LOQs of the method for such microelements as $\mathrm{Cu}, \mathrm{Cr}, \mathrm{Zn}, \mathrm{Mn}, \mathrm{Fe}, \mathrm{Ni}$, and Co amounted to 0.027, 0.003, $0.06,0.06,0.03,0.006$, and $0.009 \mathrm{mg} / 100 \mathrm{~g}$, respectively. LOQs for toxic elements $\mathrm{Pb}$ and $\mathrm{Cd}$ were equal to 0.012 and $0.009 \mathrm{mg} / 100 \mathrm{~g}$, respectively. The limit of detection and limit of quantification were established according to Konieczka and Namieśnik [13], i.e. LOD = blank mean + 3SD; LOQ = 3LOD.

In order to validate the analytical protocol, linearity was also evaluated by determining the square correlation coefficients of the calibration curves generated by injections of standard solutions. The data concerning method's linearity are summarized in Table 4.

\section{Statistical Analysis}

The results were subjected to statistical analysis, i.e., Spearman rank correlation analysis, Kruskal-Wallis test, factor analysis (FA), and cluster analysis (CA), using Statistica 10 (StatSoft®). All selected variables were tested for normality using Shapiro-Wilk test, and normal distribution was not confirmed; thus, non-parametric tests were applied [14]. Data were first subjected to standardization. The data matrix was established using the elements as columns and tea samples as rows. All of the elements were taken into account in the analysis and proved to have a great contribution to sample differentiation. In cluster analysis (CA), the best results were obtained for the Ward's method using Euclidean distance.

\section{Results and Discussion}

The results concerning the analyzed elements in Pu-erh and fruit teas are listed in Table 5. All the element concentrations (wet weight basis) in tea samples are characterized by arithmetic mean value, the corresponding standard deviation (SD), and ranges.

Pu-erh Tea Pu-erh tea was characterized by high levels of $\mathrm{K}$, $\mathrm{P}, \mathrm{Ca}$, and $\mathrm{Mg}$ (2653, 1421, 872, and $322 \mathrm{mg} / 100 \mathrm{~g}$, respectively), and these elements were more abundant in leaf tea than in tea bags. The content of $\mathrm{Na}$ in marketed Pu-erh tea bags $(27.1 \mathrm{mg} / 100 \mathrm{~g})$ was higher than in a loose form $(16.2 \mathrm{mg} / 100 \mathrm{~g})$, which is in agreement with results published by McKenzie et al. [15]. Similar results to our study were reported by Malik et al. [16] for such elements as $\mathrm{Ca}, \mathrm{K}$, and $\mathrm{Mg}$ amounting to 716, 2176, and $297 \mathrm{mg} / 100 \mathrm{~g}$, respectively. The highest percentage of leaching was recorded for $\mathrm{K}$ and $\mathrm{Na}$ (46.7-56.9 and 40.6-45.3\%, respectively) and the lowest for $\mathrm{Ca}$ (9.90-15.9\%). Among microelements, the highest concentration was determined for $\mathrm{Mn}(77.2 \mathrm{mg} / 100 \mathrm{~g})$ in marketed tea bags and the lowest for Co $(0.03 \mathrm{mg} / 100 \mathrm{~g})$ in loose form of Pu-erh tea. In general, higher levels of $\mathrm{Fe}, \mathrm{Co}$, $\mathrm{Cr}$, and $\mathrm{Pb}$ were noted for tea bags than loose tea. Seenivasan et al. [17, 18] suggested that high $\mathrm{Cr}$ content in tea can be explained by the contamination of tea primarily from soil and CTC rollers during tea production. The results obtained for $\mathrm{Cu}$ in both forms of Pu-erh tea $(1.93 \mathrm{mg} / 100 \mathrm{~g})$ are similar to those reported by Cao et al. [19] (2.10 mg/100 g) and Malik et al. [16] (2.10 mg/100 g). Pu-erh tea in loose form contained more $\mathrm{Ni}(0.60 \mathrm{mg} / 100 \mathrm{~g})$ as compared with black tea with fruit $(0.46 \mathrm{mg} / 100 \mathrm{~g})$. Zinc and Fe levels (3.80 and $32.0 \mathrm{mg} / 100 \mathrm{~g}$, respectively) were similar to those obtained by McKenzie et al. [15] (3.40 and $38.0 \mathrm{mg} / 100 \mathrm{~g}$, respectively). The lowest percentages of leaching in tea bags were noted for $\mathrm{Fe}, \mathrm{Cd}, \mathrm{Co}$, 
Table 3 Measurements of bioelements and toxic metal concentrations in reference materials, i.e., Tea NCS

ZC73014, Oriental Basma Tobacco Leaves INCT-OBTL-5, and Polish Virginia Tobacco Leaves INCT-PVTL-6

\begin{tabular}{|c|c|c|c|c|}
\hline Element & $\begin{array}{l}\text { Certified concentration } \\
(\mathrm{mg} / 100 \mathrm{~g})\end{array}$ & $\begin{array}{l}\text { Concentration determined } \\
(\mathrm{mg} / 100 \mathrm{~g})\end{array}$ & $\operatorname{RSD}(\%)$ & Recovery (\%) \\
\hline $\mathrm{Ca}^{\mathrm{a}}$ & $3260 \pm 80$ & $2818 \pm 123$ & 4.38 & 86 \\
\hline $\mathrm{Ca}^{\mathrm{b}}$ & $3859 \pm 142$ & $3566 \pm 149$ & 4.17 & 92 \\
\hline $\mathrm{Ca}^{\mathrm{c}}$ & $2297 \pm 78$ & $2513 \pm 13.4$ & 0.5 & 109 \\
\hline $\mathrm{Co}^{\mathrm{a}}$ & $0.22 \pm 0.02$ & $0.21 \pm 0.03$ & 10.3 & 95 \\
\hline $\mathrm{Co}^{\mathrm{b}}$ & $0.10 \pm 0.007$ & $0.09 \pm 0.005$ & 5.65 & 90 \\
\hline $\mathrm{Cu}^{\mathrm{a}}$ & $18.6 \pm 0.7$ & $16.9 \pm 0.02$ & 0.12 & 91 \\
\hline $\mathrm{Cu}^{\mathrm{b}}$ & $1.01 \pm 0.04$ & $1.00 \pm 0.01$ & 1.42 & 99 \\
\hline $\mathrm{Cu}^{\mathrm{c}}$ & $0.51 \pm 0.02$ & $0.54 \pm 0.01$ & 2.0 & 106 \\
\hline $\mathrm{Cd}^{\mathrm{b}}$ & $0.26 \pm 0.01$ & $0.28 \pm 0.01$ & 3.48 & 105 \\
\hline $\mathrm{Cd}^{\mathrm{c}}$ & $0.22 \pm 0.01$ & $0.21 \pm 0.001$ & 0.4 & 95 \\
\hline $\mathrm{Cr}^{\mathrm{a}}$ & $0.45 \pm 0.1$ & $0.44 \pm 0.02$ & 4.54 & 98 \\
\hline $\mathrm{Cr}^{\mathrm{b}}$ & $0.63^{\mathrm{d}}$ & $0.56 \pm 0.0001$ & 0.02 & 89 \\
\hline $\mathrm{Cr}^{\mathrm{c}}$ & $0.09^{\mathrm{d}}$ & $0.09 \pm 0.001$ & 1.3 & 98 \\
\hline $\mathrm{Mg}^{\mathrm{a}}$ & $1860 \pm 110$ & $1785 \pm 28.8$ & 1.61 & 96 \\
\hline $\mathrm{Mg}^{\mathrm{b}}$ & $853 \pm 34$ & $845 \pm 4.96$ & 0.59 & 99 \\
\hline $\mathrm{Mg}^{\mathrm{c}}$ & $241 \pm 9$ & $247 \pm 6.01$ & 2.4 & 102 \\
\hline $\mathrm{Mn}^{\mathrm{a}}$ & $500 \pm 2$ & $460 \pm 4$ & 0.87 & 92 \\
\hline $\mathrm{Mn}^{\mathrm{b}}$ & $18.0 \pm 0.6$ & $20.2 \pm 0.34$ & 1.67 & 112 \\
\hline $\mathrm{Mn}^{\mathrm{c}}$ & $13.6 \pm 0.5$ & $15.3 \pm 0.18$ & 1.2 & 113 \\
\hline $\mathrm{Zn}^{\mathrm{a}}$ & $51.0 \pm 2$ & $50.9 \pm 0.26$ & 0.51 & 100 \\
\hline $\mathrm{Zn}^{\mathrm{b}}$ & $5.24 \pm 0.18$ & $5.59 \pm 0.24$ & 4.31 & 107 \\
\hline $\mathrm{Zn}^{\mathrm{c}}$ & $4.36 \pm 0.1$ & $4.64 \pm 0.01$ & 0.3 & 106 \\
\hline $\mathrm{K}^{\mathrm{a}}$ & $16,300 \pm 700$ & $16,713 \pm 800$ & 4.79 & 102 \\
\hline $\mathrm{K}^{\mathrm{b}}$ & $2271 \pm 76$ & $2449 \pm 50.3$ & 2.06 & 108 \\
\hline $\mathrm{K}^{\mathrm{c}}$ & $2640 \pm 90$ & $2692 \pm 31.6$ & 1.2 & 102 \\
\hline $\mathrm{Na}^{\mathrm{a}}$ & $90 \pm 10$ & $88 \pm 9$ & 10.2 & 98 \\
\hline $\mathrm{Na}^{\mathrm{c}}$ & $6.24^{\mathrm{d}}$ & $5.50 \pm 0.03$ & 0.5 & 88 \\
\hline $\mathrm{Pb}^{\mathrm{a}}$ & $1.5 \pm 0.2$ & $1.41 \pm 0.03$ & 2.13 & 94 \\
\hline $\mathrm{Pb}^{\mathrm{b}}$ & $0.20 \pm 0.03$ & $0.19 \pm 0.01$ & 5.6 & 95 \\
\hline $\mathrm{Pb}^{\mathrm{c}}$ & $0.10 \pm 0.01$ & $0.09 \pm 0.01$ & 10.3 & 89 \\
\hline $\mathrm{P}^{\mathrm{a}}$ & $4500 \pm 0.3$ & $4650 \pm 0.5$ & 0.11 & 103 \\
\hline $\mathrm{P}^{\mathrm{b}}$ & $170 \pm 12$ & $170 \pm 0.41$ & 0.24 & 100 \\
\hline $\mathrm{P}^{\mathrm{c}}$ & $242 \pm 5$ & $239 \pm 0.96$ & 0.4 & 99 \\
\hline $\mathrm{Ni}^{\mathrm{a}}$ & $3.4 \pm 0.3$ & $3.2 \pm 0.02$ & 0.62 & 94 \\
\hline $\mathrm{Ni}^{\mathrm{b}}$ & $0.85 \pm 0.05$ & $0.80 \pm 0.078$ & 9.8 & 94 \\
\hline $\mathrm{Ni}^{\mathrm{c}}$ & $0.15 \pm 0.01$ & $0.13 \pm 0.001$ & 0.6 & 87 \\
\hline $\mathrm{Fe}^{\mathrm{a}}$ & $242 \pm 18$ & $244 \pm 14$ & 5.74 & 101 \\
\hline $\mathrm{Fe}^{\mathrm{b}}$ & $149^{\mathrm{d}}$ & $160 \pm 1.01$ & 0.63 & 107 \\
\hline $\mathrm{Fe}^{\mathrm{c}}$ & $25.8^{\mathrm{d}}$ & $28 \pm 0.30$ & 1.1 & 109 \\
\hline
\end{tabular}

${ }^{\mathrm{a}}$ Tea NCS ZC73014

${ }^{\mathrm{b}}$ Oriental Basma Tobacco Leaves INCT-OBTL-5

${ }^{\mathrm{c}}$ Polish Virginia Tobacco Leaves INCT-PVTL-6

${ }^{\mathrm{d}}$ Information value
$\mathrm{Ca}$, and $\mathrm{Cu}(1.65,2.80,3.81,9.90$, and $11.6 \%$, respectively). Karak and Bhagat [20] reported comparable results of leaching $\mathrm{Cr}(16.0 \%)$ to our study (Cr $20.0 \%)$. Lead and Cd levels in samples of Pu-erh tea amounted to $0.06 \mathrm{mg}$ and $0.02 \mathrm{mg} / 100 \mathrm{~g}$, respectively. Comparable results for Cd were reported by Lv et al. [21] (0.02 mg/100 g). 
Table 4 Validation data of the analytical methodology

\begin{tabular}{llll}
\hline Element & Linearity & & \\
\cline { 2 - 4 } & Calibration curve range $(\mu \mathrm{g} / \mathrm{mL})$ & Calibration curve & $R^{2}$ \\
\hline $\mathrm{Ca}$ & $2.00-15.0$ & $y=0.06587 x+0.0198$ & 0.999 \\
$\mathrm{~K}$ & $0.50-1.50$ & $y=0.00041 x+0.0052$ & 0.999 \\
$\mathrm{Mg}$ & $0.30-0.90$ & $y=0.00131 x+0.0236$ & 0.998 \\
$\mathrm{Na}$ & $0.50-1.20$ & $y=0.00065 x+0.0120$ & 0.998 \\
$\mathrm{P}$ & $0.10-1.20$ & $y=0.00444 x+0.0117$ & 0.999 \\
$\mathrm{Mn}$ & $0.15-5.00$ & $y=0.00015 x+0.0067$ & 0.999 \\
$\mathrm{Fe}$ & $1.00-10.0$ & $y=0.05768 x+0.0065$ & 0.998 \\
$\mathrm{Zn}$ & $0.20-1.00$ & $y=0.00037 x+0.0040$ & 0.999 \\
$\mathrm{Cu}$ & $0.50-4.00$ & $y=0.00011 x+0.0049$ & 0.999 \\
$\mathrm{Co}$ & $1.00-5.00$ & $y=0.00006 x+0.0053$ & 0.999 \\
$\mathrm{Cd}$ & $0.20-2.00$ & $y=0.00021 x+0.0067$ & 0.998 \\
$\mathrm{Cr}$ & $0.20-2.00$ & $y=0.00006 x+0.0013$ & 0.999 \\
$\mathrm{Ni}$ & $0.50-2.00$ & $y=0.00006 x+0.0008$ & 0.999 \\
$\mathrm{~Pb}$ & $0.20-2.00$ & $y=0.00005 x+0.0001$ & 0.999 \\
\hline
\end{tabular}

Fruit Tea The highest K and Ca levels (1113 and $727 \mathrm{mg} /$ $100 \mathrm{~g}$, respectively) were determined in teas consisting only from fruits. In case of black teas with fruit additions, the highest values among macroelements were recorded for $\mathrm{K}$ and $P(1275$ and $881 \mathrm{mg} / 100 \mathrm{~g})$. Similar $\mathrm{K}$ values $(1135 \mathrm{mg} / 100 \mathrm{~g})$ were reported by McKenzie et al. [15]. Black tea with fruit analyzed in our study was characterized by higher values of $\mathrm{P}(881 \mathrm{mg} / 100 \mathrm{~g})$ as compared with results obtained by McKenzie et al. [15] for black teas $(286 \mathrm{mg} /$ $100 \mathrm{~g})$. Bioelements that characterized with the highest percentages of leaching were $\mathrm{K}(68.4-76.5 \%)$ and $\mathrm{Na}(56.6-$ $67.7 \%)$. Among microelements, the lowest level was determined for $\mathrm{Co}(0.03 \mathrm{mg} / 100 \mathrm{~g})$, which is comparable to results obtained by Pękal et al. [22] (0.02 mg/100 g). Among microelements, the highest levels were obtained for $\mathrm{Mn}$ in black tea with fruits $(76.2 \mathrm{mg} / 100 \mathrm{~g})$. Similar values for Mn $(64.0 \mathrm{mg} /$ $100 \mathrm{~g}$ ) were reported by Mehra and Baker [23]. Jonah and Williams [24] suggested that tea foliage accumulates $\mathrm{Mn}$ in appreciable quantities with values as high as $100 \mathrm{mg} / 100 \mathrm{~g}$ in tea leaf grown in acid soils, which is in agreement with our study (Pu-erh tea and black tea with fruit). Black teas with fruit additions contained lower levels of $\mathrm{Fe}(21.8 \mathrm{mg} / 100 \mathrm{~g})$ than fruit teas. This result is in agreement with values published by Ashraf et al. [25] and Zeyuan et al. [7]. Based on our results, it was also concluded that fruit teas contained more $\mathrm{Pb}$ than black teas with fruits, whereas $\mathrm{Cd}$ in both kinds of tea was on the same level $(0.02 \mathrm{mg} / 100 \mathrm{~g})$. Jin et al. [26] reported that black tea leaves contained $\mathrm{Pb}$ in the range of 0.02 and $0.04 \mathrm{mg} / 100 \mathrm{~g}$. The highest percentage of leaching was recorded for Ni and ranged from 42.6 to $66.8 \%$.

Differences in element concentration in infusions might be explained by chelation of these elements with tannic acid and tannins which exudate during the boiling of tea. Dambiec et al.
[27] and Wróbel et al. [28] reported that lower content of tannins in tea results in better extraction of elements to the infusion.

\section{Correlation Analysis}

Correlation analysis was performed using the nonparametric Spearman rank test for the analyzed elements at three levels of significance $(p<0.05, p<0.01, p<0.001)$. The most significant positive relationships $(p<0.001)$ in $\mathrm{Pu}$-erh tea were noted for P-Zn, P-Ni, K-Ni, K-Zn, Fe-Co, Fe-Cr, Fe-Pb, Co$\mathrm{Cr}$, and $\mathrm{Cr}-\mathrm{Pb}$. In case of fruit teas, such significant positive interdependences were recorded for $\mathrm{Mg}-\mathrm{Fe}, \mathrm{P}-\mathrm{Ni}$, and $\mathrm{Co}-\mathrm{Ni}$.

\section{Kruskal-Wallis Test}

Kruskal-Wallis test was performed for Pu-erh and fruit teas. It was found that the type of tea confection (loose or tea bag) is linked to concentrations of such elements as $\mathrm{Fe}(H=10.000$; $p=0.0016), \mathrm{Co}(H=7.511 ; p=0.006), \mathrm{Cr}(H=10.000$; $p=0.002), \mathrm{Pb}(H=6.944 ; p=0.008)$, and $\mathrm{Na}(H=4.444$; $p=0.035)$. Strong interdependences were also observed in samples of fruit teas and black teas with fruit additions for such elements as $\mathrm{P}(H=9.422 ; p=0.002), \mathrm{Mn}(H=10.500$; $p=0.001), \mathrm{Fe}(H=4.339 ; p=0.037), \mathrm{Ni}(H=10.500$; $p=0.001)$, and $\mathrm{Cd}(H=7.085 ; p=0.008)$. The null hypothesis of Kruskal-Wallis test was rejected, so a post hoc test for the multiple comparisons was applied, which allowed on differences' identification. Several elements have been identified as being dependent on the type of tea and its sort of confection. However, such interdependences were not found in case of $\mathrm{Ca}$. What is interesting, it was found that $\mathrm{Cr}$ is strongly 
Table 5 Concentration of bioelements and toxic metals in $\mathrm{Pu}$-erh (loose/bags) and fruit tea (bags) samples in milligrams/ $100 \mathrm{~g}$ w.w. ( $x \pm \mathrm{SD}$, range) and an average percentage of leaching (\%)

\begin{tabular}{|c|c|c|c|c|}
\hline Elements & $\begin{array}{l}\text { Pu-erh loose form } \\
\text { (China) }\end{array}$ & $\begin{array}{l}\text { Pu-erh tea bags } \\
\text { (marketed) }\end{array}$ & $\begin{array}{l}\text { Fruit tea } \\
\text { (tea bags) }\end{array}$ & $\begin{array}{l}\text { Black tea with fruit } \\
\text { (tea bags) }\end{array}$ \\
\hline$n$ & $12 \times 6$ & $5 \times 6$ & $7 \times 6$ & $8 \times 6$ \\
\hline \multirow[t]{3}{*}{$\mathrm{Ca}$} & $872 \pm 352$ & $657 \pm 144$ & $727 \pm 154$ & $632 \pm 318$ \\
\hline & $(325-1437)$ & $(457-845)$ & $(531-978)$ & $(120-1020)$ \\
\hline & $15.9 \pm 19.7 \%$ & $9.90 \pm 6.71 \%$ & $42.9 \pm 11.4 \%$ & $25.3 \pm 19.1 \%$ \\
\hline \multirow[t]{3}{*}{ K } & $2653 \pm 186$ & $2457 \pm 454$ & $1113 \pm 555$ & $1275 \pm 137$ \\
\hline & $(2386-3085)$ & $(1742-3141)$ & $(410-2167)$ & $(1008-1467)$ \\
\hline & $56.9 \pm 19.7 \%$ & $46.7 \pm 19.1 \%$ & $76.5 \pm 8.86 \%$ & $68.4 \pm 17.5 \%$ \\
\hline \multirow[t]{3}{*}{$\mathrm{Mg}$} & $322 \pm 49.2$ & $307 \pm 45.0$ & $193 \pm 88.8$ & $118 \pm 26.0$ \\
\hline & $(271-397)$ & $(242-379)$ & $(90.1-336)$ & $(79.6-151)$ \\
\hline & $17.8 \pm 7.35 \%$ & $25.4 \pm 3.88 \%$ & $55.0 \pm 20.2 \%$ & $56.6 \pm 4.69 \%$ \\
\hline \multirow[t]{3}{*}{$\mathrm{Na}$} & $16.2 \pm 5.40$ & $27.1 \pm 13.1$ & $11.8 \pm 4.73$ & $8.32 \pm 5.08$ \\
\hline & $(10.0-27.6)$ & $(15.0-50.6)$ & $(4.11-18.4)$ & $(3.89-17.6)$ \\
\hline & $40.6 \pm 13.1 \%$ & $45.3 \pm 18.9 \%$ & $67.7 \pm 24.8 \%$ & $56.9 \pm 23.2 \%$ \\
\hline \multirow[t]{3}{*}{$\mathrm{P}$} & $1421 \pm 180$ & $1356 \pm 208$ & $519 \pm 134$ & $881 \pm 64.0$ \\
\hline & $(1261-1940)$ & $(948-1526)$ & $(334-781)$ & $(778-979)$ \\
\hline & $26.6 \pm 2.21 \%$ & $23.6 \pm 1.10 \%$ & $15.0 \pm 3.50 \%$ & $14.5 \pm 1.67 \%$ \\
\hline \multirow[t]{3}{*}{$\mathrm{Mn}$} & $77.2 \pm 12.0$ & $76.6 \pm 10.4$ & $21.7 \pm 5.82$ & $76.2 \pm 27.6$ \\
\hline & $(47.3-94.2)$ & $(56.7-84.9)$ & $(13.0-30.0)$ & $(34.0-115)$ \\
\hline & $15.7 \pm 3.42 \%$ & $15.8 \pm 3.04 \%$ & $56.2 \pm 8.28 \%$ & $19.5 \pm 6.94 \%$ \\
\hline \multirow[t]{3}{*}{$\mathrm{Fe}$} & $32.2 \pm 5.81$ & $68.3 \pm 10.2$ & $33.7 \pm 10.7$ & $21.8 \pm 6.93$ \\
\hline & $(16.8-41.6)$ & $(50.9-78.3)$ & $(18.2-50.2)$ & $(14.0-35.4)$ \\
\hline & $2.37 \pm 0.71 \%$ & $1.65 \pm 0.36 \%$ & $2.64 \pm 1.07 \%$ & $0.91 \pm 0.55 \%$ \\
\hline \multirow[t]{3}{*}{$\mathrm{Zn}$} & $3.84 \pm 0.42$ & $3.77 \pm 0.68$ & $2.04 \pm 0.52$ & $2.6 \pm 0.53$ \\
\hline & $(3.38-4.73)$ & $(2.45-4.43)$ & $(1.47-3.00)$ & $(1.95-3.60)$ \\
\hline & $29.1 \pm 12.6 \%$ & $32.2 \pm 7.73 \%$ & $46.0 \pm 17.0 \%$ & $39.2 \pm 13.9 \%$ \\
\hline \multirow[t]{3}{*}{$\mathrm{Cu}$} & $1.93 \pm 0.17$ & $1.94 \pm 0.38$ & $0.47 \pm 0.10$ & $1.1 \pm 0.81$ \\
\hline & $(1.66-2.21)$ & $(1.27-2.44)$ & $(0.38-0.65)$ & $(0.14-2.72)$ \\
\hline & $5.15 \pm 3.98 \%$ & $11.6 \pm 2.00 \%$ & $31.9 \pm 7.95 \%$ & $43.1 \pm 27.3 \%$ \\
\hline \multirow[t]{3}{*}{ Co } & $0.02 \pm 0.005$ & $0.03 \pm 0.006$ & $0.02 \pm 0.01$ & $0.04 \pm 0.02$ \\
\hline & $(0.01-0.03)$ & $(0.02-0.04)$ & $(0.01-0.04)$ & $(0.02-0.06)$ \\
\hline & $3.76 \pm 1.47 \%$ & $3.81 \pm 0.35 \%$ & $3.62 \pm 2.69 \%$ & $2.12 \pm 1.31 \%$ \\
\hline \multirow[t]{3}{*}{$\mathrm{Cd}$} & $0.02 \pm 0.001$ & $0.02 \pm 0.001$ & $0.02 \pm 0.003$ & $0.02 \pm 0.001$ \\
\hline & $(0.02-0.02)$ & $(0.02-0.02)$ & $(0.02-0.03)$ & $(0.02-0.02)$ \\
\hline & $4.67 \pm 2.44 \%$ & $2.80 \pm 1.40 \%$ & $8.24 \pm 4.29 \%$ & $5.18 \pm 1.73 \%$ \\
\hline \multirow[t]{3}{*}{$\mathrm{Cr}$} & $0.15 \pm 0.03$ & $0.33 \pm 0.04$ & $0.24 \pm 0.09$ & $0.22 \pm 0.13$ \\
\hline & $(0.09-0.19)$ & $(0.28-0.38)$ & $(0.09-0.41)$ & $(0.08-0.48)$ \\
\hline & $45.6 \pm 15.4 \%$ & $20.0 \pm 2.78 \%$ & $40.4 \pm 30.2 \%$ & $29.2 \pm 7.70 \%$ \\
\hline \multirow[t]{3}{*}{$\mathrm{Ni}$} & $0.60 \pm 0.06$ & $0.52 \pm 0.08$ & $0.19 \pm 0.04$ & $0.46 \pm 0.09$ \\
\hline & $(0.49-0.71)$ & $(0.36-0.60)$ & $(0.12-0.25)$ & $(0.35-0.57)$ \\
\hline & $34.3 \pm 17.1 \%$ & $45.3 \pm 2.86 \%$ & $42.6 \pm 14.2 \%$ & $66.8 \pm 11.7 \%$ \\
\hline \multirow[t]{3}{*}{$\mathrm{Pb}$} & $0.04 \pm 0.02$ & $0.09 \pm 0.03$ & $0.01 \pm 0.002$ & $0.01 \pm 0.008$ \\
\hline & $(<\mathrm{LOD}-0.08)$ & $(0.04-0.13)$ & $(<\mathrm{LOD}-0.03)$ & $(<\mathrm{LOD}-0.02)$ \\
\hline & $37.2 \pm 22.9 \%$ & $15.8 \pm 3.28 \%$ & $43.1 \pm 23.0 \%$ & $43.8 \pm 29.5 \%$ \\
\hline
\end{tabular}

$n$ number of samples multiplied by number of analytical subsamples correlated only with the sort of confection, which can imply the influence of technological processing. All the results are presented in the Table 6 . The results of post hoc analysis confirm the outcome of factor analysis. 
Table 6 Results of the post hoc test conducted for the analyzed data matrix

\begin{tabular}{lllll}
\hline & Pu-erh loose tea & Pu-erh bags & Fruit tea & Black tea with fruit additions \\
\hline Pu-erh loose tea & - & $\mathrm{Cr}$ & $\mathrm{K}, \mathrm{P}, \mathrm{Mn}, \mathrm{Zn}, \mathrm{Cu}, \mathrm{Ni}$ & $\mathrm{K}, \mathrm{Mg}, \mathrm{P}, \mathrm{Zn}, \mathrm{Co}, \mathrm{Cd}, \mathrm{Pb}$ \\
Pu-erh bags & $\mathrm{Cr}$ & - & $\mathrm{K}, \mathrm{P}, \mathrm{Mn}, \mathrm{Zn}, \mathrm{Cu}, \mathrm{Pb}$ & $\mathrm{Mg}, \mathrm{Na}, \mathrm{P}, \mathrm{Fe}, \mathrm{Cd}, \mathrm{Pb}$ \\
\hline
\end{tabular}

There are only given elements for which $p<0.05$
Kruskal-Wallis test conducted by McKenzie et al. [15] revealed that there are strong interdependences in tea samples for elements: $\mathrm{Mn}, \mathrm{Zn}, \mathrm{Fe}, \mathrm{P}$, and $\mathrm{Na}$ in view of geographical origin. Similarly, Moreda-Pineiro et al. [29] found statistically significant differences for $\mathrm{Fe}, \mathrm{Mn}$, and $\mathrm{Pb}$ for tea samples in view of geographical origin.

\section{Factor Analysis}

Factor analysis (FA), which was performed on raw data sets of $\mathrm{Pu}$-erh and fruit teas, revealed two factors (F1 and F2) that cumulatively explain $61.36 \%$ of the total variance $(\mathrm{F} 1=43.93 \%$ and $\mathrm{F} 2=17.42 \%)$. Eigenvalues amounted to 8.59 for F1 and 6.15 for F2. It can be observed on Fig. 1a that samples of Pu-erh tea (lower values of F1) are clearly distinguished from fruit teas characterized by higher values of $\mathrm{F} 1$ (Fig. 1a). The scatterplot of loadings was drawn for F1-F2 in order to identify elements responsible for the grouping of objects (Fig. 1b). Factor 1 reveals a high (negative) correlation to $\mathrm{P}, \mathrm{K}, \mathrm{Zn}, \mathrm{Cu}, \mathrm{Ni}, \mathrm{Mg}$ and $\mathrm{Pb}, \mathrm{Mn}, \mathrm{Fe}$, and $\mathrm{Na}$, which characterize Pu-erh teas that contain higher levels of these elements (Table 5) than fruit teas and black teas with fruit additions. That is why, Pu-erh teas appeared at more negative values of F1 than fruity ones (Fig. 1a). Additionally, F2 explains the sample differentiation, cumulatively with $\mathrm{F} 1$, as there is clear diversification in view of the type of confection among Pu-erh tea samples (lower F1 values). Higher values of F2 and lower of F1, which are identified by $\mathrm{P}, \mathrm{Zn}, \mathrm{Ni}, \mathrm{K}, \mathrm{Cu}, \mathrm{Mg}$, and $\mathrm{Mn}$, can be associated with loose form of Pu-erh samples, whereas F2 lower values (lower F1 values) correspond to Pu-erh tea bags, characterized by $\mathrm{Fe}$ and $\mathrm{Cr}$ (Fig. 1a, b). Chromium and Fe are strongly negatively correlated $(>0.7)$, and their concentrations are significantly varied in loose and bags teas. Although $\mathrm{Pb}, \mathrm{Na}$, and $\mathrm{Co}$ characterize with negative F2 loadings ( $>0.4)$, there are no significant differences in their levels in the analyzed teas.

Simultaneously, F2 is helpful in obtaining extra information concerning fruit and black teas with fruit addition samples, which are described by higher values of F1. Although, these samples partially overlap, but there is also observed diversification according to their type, i.e., black tea with fruit additions are characterized by $\mathrm{Ca}$, and higher values of $\mathrm{F} 1$ and F2 (Fig. 1a, b). Although $\mathrm{Cr}$ and $\mathrm{Fe}$ are strongly negatively correlated with F2, there are no significant differences in their concentrations in both groups of fruit teas; thus, they are not differentiating these samples (Table 6).
Based on the conducted analysis, it can be concluded that $\mathrm{F} 1$ is a factor responsible for differentiation of samples in view of the tea type (Pu-erh and fruit teas). However, factor 2 provides additional to $\mathrm{F} 1$ information concerning the analyzed samples, and both of them cumulatively are responsible for the diversification within the group of fruit tea, i.e., pure fruit tea from black tea with fruit additions as well as Pu-erh tea in view of its confection (loose form-tea bags) which is usually associated with its quality.

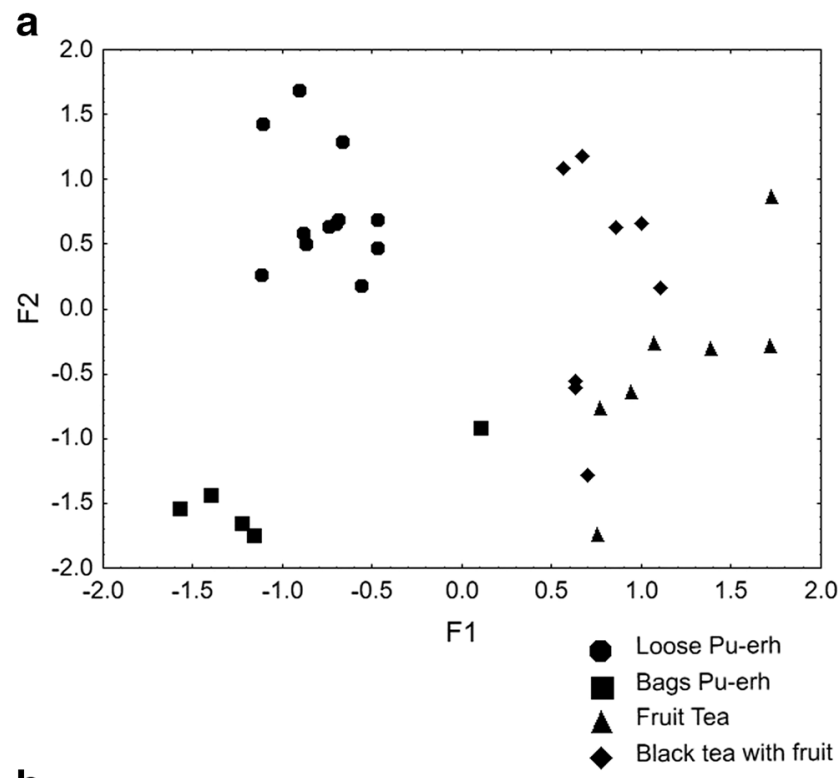

b

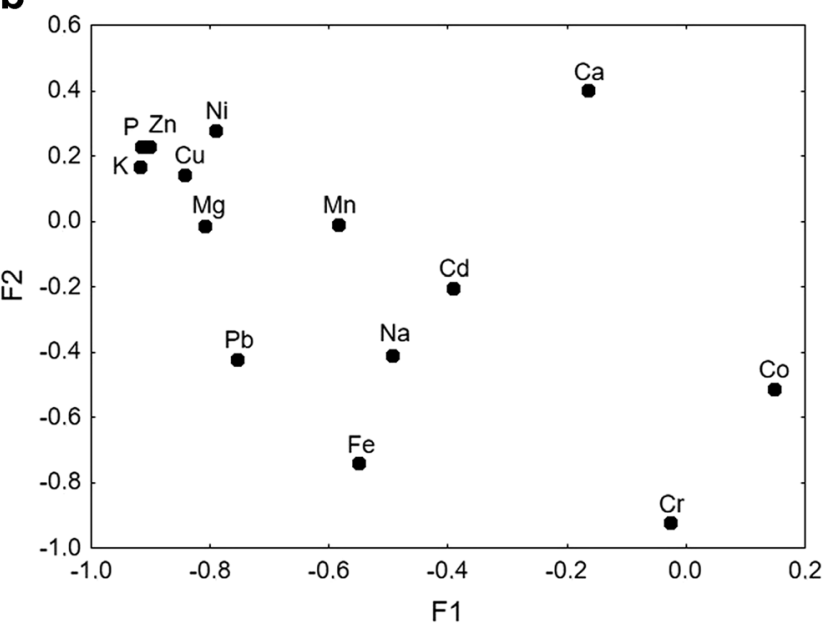

Fig. 1 a Scatterplot of object samples of two discriminant functions of the all analyzed tea samples. b Scatterplot of loadings for 14 elements in all the analyzed tea samples 
Most of the authors differentiated teas in view of their type and geographical origin [15, 29-31]. In our study, tea diversification was achieved according to its kind and type of confection.

\section{Cluster Analysis}

The cluster analysis (CA) was performed using Ward method and Euclidean distance on data concerning Pu-erh and fruit tea samples. Figure 2 presents the outcome of the conducted analysis, i.e., the dendrogram which is built of four main clusters containing samples grouped according to the type of confection (loose, tea bag) and kind of tea (Pu-erh tea, fruit tea, and black tea with fruits). The first cluster contains samples of black tea with fruit additions which characterized with the lowest $\mathrm{Ca}$ levels among all analyzed samples. Next to them, there can be distinguished cluster with fruit tea samples that were differentiated in this analysis by $\mathrm{Mg}$ and $\mathrm{K}$, which are metals of natural soil origin. It is understandable as fruits are usually reckoned as sources of $\mathrm{Mg}$ and $\mathrm{K}$ [32]. However, in case of Pu-erh tea samples, differentiation was based on metals of anthropogenic origin. Chromium, Co, and $\mathrm{Fe}$ proved to be good descriptors of type of tea confection, which can be observed on Fig. 2, where the third and the fourth clusters correspond to Pu-erh tea bags and $\mathrm{Pu}$-erh loose tea, respectively. In case of $\mathrm{Cr}$, there can be observed higher levels of this metal in tea bags mainly due to the applied technological processing, i.e., CTC $[17,18]$.

As can be observed, CA made it possible to differentiate tea samples in view of the tea quality and its type with respect to the chemical composition of the analyzed samples.

\section{Recommended Dietary Intake}

The recommended daily intake (RDA) was calculated for $\mathrm{Pu}$ erh and fruit tea infusions according to the latest available Polish [33] and American recommendations [34]. RDAs for macroelements such as $\mathrm{Ca}, \mathrm{K}, \mathrm{Na}, \mathrm{Mg}$, and $\mathrm{P}$, through consumption of $200 \mathrm{~mL}$ of Pu-erh and fruit teas, were realized from 0.007 to $1.00 \%$ (Table 7). Similar percentages of the RDA realization can be observed in the case of $\mathrm{Zn}$ and Fe. Chromium, $\mathrm{Ni}, \mathrm{Cu}$, and $\mathrm{Co}$ were under the limit of detection; thus, there could not have been estimated the percentage of recommended daily intake realization for these elements $(\mathrm{Cr}<0.001 \mathrm{mg} / 100 \mathrm{~g}, \mathrm{Ni}<0.002 \mathrm{mg} / 100 \mathrm{~g}$, $\mathrm{Cu}<0.009 \mathrm{mg} / 100 \mathrm{~g}$, and $\mathrm{Co}<0.003 \mathrm{mg} / 100 \mathrm{~g}$ ). The highest RDA realization through consumption of one cup daily was recorded for $\mathrm{Mn}$ (10.0-15.0\%), which constitutes significant values, but its bioavailability to human body should be also taken into account. According to Powell et al. [35], Mn in simulated intestinal conditions was bioavailable in $40.0 \%$. It means that only about $50.0 \%$ of Mn determined in the studied $\mathrm{Pu}$-erh and fruit tea samples was bioavailable. Mossion et al. [36] also suggested that water composition plays an important role in chemical extraction of elements from tea leaves and strongly determines tea infusion composition. Additionally, it is a well-known fact that there are many anti-nutritive substances in tea such as oxalate or tannins which can absorb many metals in solution. According to the World Health Organization (WHO), the provisional tolerable weekly intake (PTWI) for Cd should not exceed $7 \mu \mathrm{g} / \mathrm{kg}$, for a person weighing $70 \mathrm{~kg}$. In case of $\mathrm{Pb}$, the $73 \mathrm{rd}$ report of the Joint FAO/WHO Expert Committee on Food Additives [37] announced that its PTWI, which previously amounted to
Fig. 2 Hierarchical dendrogram for the analyzed tea samples as objects

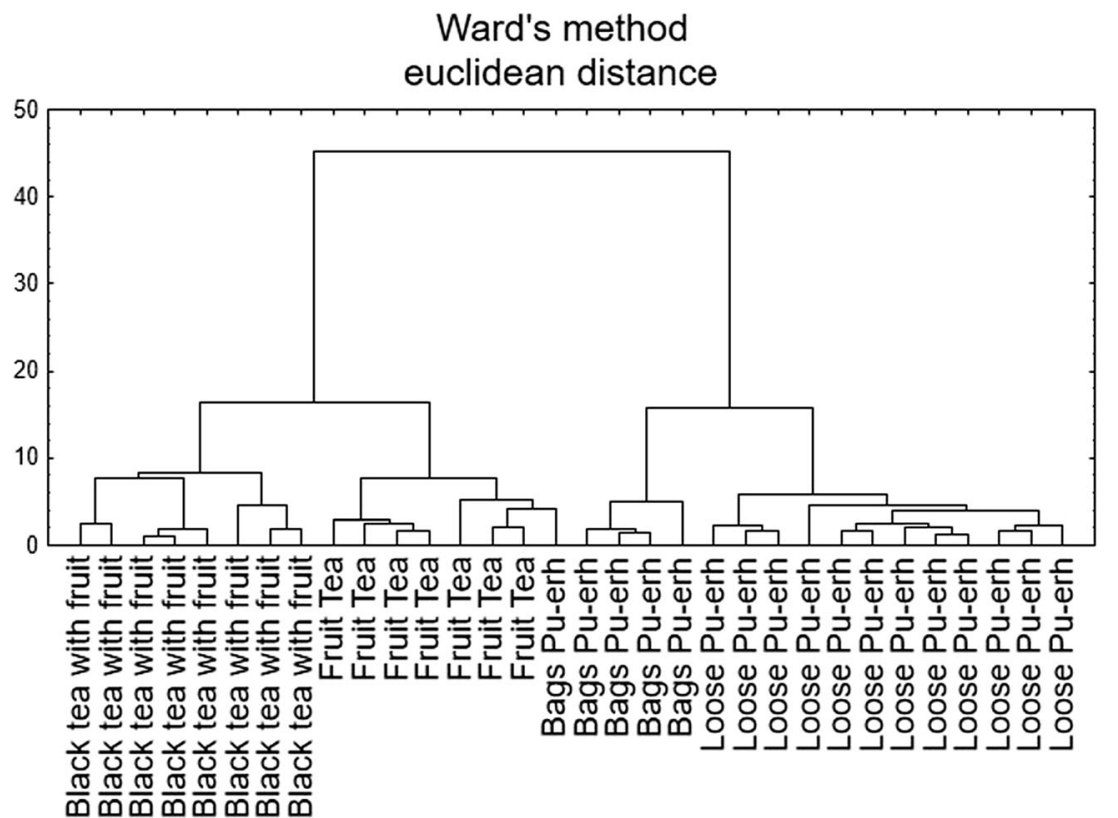


Table 7 Realization of the recommended dietary intake through consumption of one cup ( $200 \mathrm{~mL}$ ) of Pu-erh (loose/bags) and fruit tea/black tea with fruit

\begin{tabular}{|c|c|c|c|c|c|c|c|c|}
\hline \multirow[t]{2}{*}{ Element } & \multicolumn{2}{|c|}{$\begin{array}{l}\text { Recommended daily } \\
\text { allowance (RDA) } \\
\text { (mg/day/person) }\end{array}$} & \multirow[t]{2}{*}{$\begin{array}{l}\text { Pu-erh (loose/bags) } \\
\text { Average content } \\
(\mathrm{mg} / 200 \mathrm{~mL})\end{array}$} & \multirow[t]{2}{*}{$\begin{array}{l}\text { Fruit tea/black } \\
\text { tea with fruit } \\
\text { Average content } \\
(\mathrm{mg} / 200 \mathrm{~mL})\end{array}$} & \multicolumn{2}{|c|}{$\begin{array}{l}\text { Pu-erh (loose/bags) } \\
\text { Realization of RDA through } \\
\text { consumption of } 200 \mathrm{~mL} \text { of } \\
\text { infusion }(\%)\end{array}$} & \multicolumn{2}{|c|}{$\begin{array}{l}\text { Fruit tea/black tea with fruit } \\
\text { Realization of RDA through } \\
\text { consumption of } 200 \mathrm{~mL} \text { of } \\
\text { infusion }(\%)\end{array}$} \\
\hline & $\begin{array}{l}\text { Male } \\
\text { (31-50 years) }\end{array}$ & $\begin{array}{l}\text { Female } \\
(31-50 \text { years })\end{array}$ & & & $\begin{array}{l}\text { Male } \\
\text { (31-50 years) }\end{array}$ & $\begin{array}{l}\text { Female } \\
\text { ( } 31-50 \text { years) }\end{array}$ & $\begin{array}{l}\text { Male } \\
\text { (31-50 years) }\end{array}$ & $\begin{array}{l}\text { Female } \\
\text { (31-50 years) }\end{array}$ \\
\hline $\mathrm{Ca}$ & 1000 & 1000 & $\begin{array}{l}1.60 \pm 1.11 \\
0.19-4.70\end{array}$ & $\begin{array}{l}4.00 \pm 2.66 \\
0.09-7.64\end{array}$ & 0.16 & 0.16 & 0.40 & 0.40 \\
\hline $\mathrm{K}$ & 4700 & 4700 & $\begin{array}{l}28.2 \pm 11.8 \\
13.3-49.9\end{array}$ & $\begin{array}{l}17.3 \pm 6.79 \\
5.26-33.4\end{array}$ & 0.60 & 0.60 & 0.37 & 0.37 \\
\hline $\mathrm{Mg}$ & 420 & 320 & $\begin{array}{l}1.27 \pm 0.51 \\
0.38-2.28\end{array}$ & $\begin{array}{l}1.66 \pm 0.74 \\
0.51-3.26\end{array}$ & 0.30 & 0.40 & 0.40 & 0.52 \\
\hline $\mathrm{Na}$ & 1500 & 1500 & $\begin{array}{l}0.17 \pm 0.11 \\
0.05-0.45\end{array}$ & $\begin{array}{l}0.11 \pm 0.05 \\
0.04-0.20\end{array}$ & 0.01 & 0.01 & 0.007 & 0.007 \\
\hline $\mathrm{Mn}^{\mathrm{a}}$ & 2.3 & 1.8 & $\begin{array}{l}0.24 \pm 0.04 \\
0.15-0.32\end{array}$ & $\begin{array}{l}0.28 \pm 0.14 \\
0.11-0.58\end{array}$ & 10.4 & 13.3 & 12.2 & 15.5 \\
\hline $\mathrm{Fe}^{\mathrm{b}}$ & 10 & 18 & $\begin{array}{l}0.02 \pm 0.005 \\
0.01-0.03\end{array}$ & $\begin{array}{l}0.01 \pm 0.01 \\
<\text { LOD- } 0.04\end{array}$ & 0.20 & 0.10 & 0.10 & 0.05 \\
\hline $\mathrm{P}$ & 700 & 700 & $\begin{array}{l}7.25 \pm 1.47 \\
4.11-11.2\end{array}$ & $\begin{array}{l}2.06 \pm 0.64 \\
1.03-2.91\end{array}$ & 1.00 & 1.00 & 0.29 & 0.29 \\
\hline $\mathrm{Zn}$ & 11 & 8 & $\begin{array}{l}0.02 \pm 0.01 \\
0.01-0.04\end{array}$ & $\begin{array}{l}0.02 \pm 0.005 \\
0.01-0.03\end{array}$ & 0.18 & 0.16 & 0.18 & 0.25 \\
\hline
\end{tabular}

\footnotetext{
${ }^{a}$ American recommendations [34]

${ }^{\mathrm{b}}$ Polish recommendations [33]

LOD for $\mathrm{Fe}=0.01 \mathrm{mg} / 100 \mathrm{~g}$
}

$25 \mu \mathrm{g} / \mathrm{kg}$ of body weight for $70 \mathrm{~kg}$ adult person, could no longer be considered health protective and was withdrawn. Moreover, the committee stated that based on the available data, it was not possible to establish a new PTWI that would be health protective [37, 38]. However, as levels of these two elements in all tea infusions were under the detection limits of the method applied $(\mathrm{Pb}<0.004 \mathrm{mg} / 100 \mathrm{~g}$ and $\mathrm{Cd}<0.003 \mathrm{mg} /$ $100 \mathrm{~g}$ ), therefore, it was concluded that there is no health hazard associated with consumption of Pu-erh and fruit teas. Similar results were obtained by [39].

In accordance with the EFSA [40] recommendations, tolerable daily intake (TDI) for Ni should not exceed $2.8 \mu \mathrm{g} / \mathrm{kg}$ for a person weighing $70 \mathrm{~kg}$. Nickel levels in all analyzed tea infusions were $<4.0 \mu \mathrm{g} / 100 \mathrm{~g}$ in $\mathrm{Pu}-$ erh (loose/bags) and fruit tea/black tea with fruits. It means that consumption of five cups of the analyzed tea do not exceed TDI (10.2\% of TDI), but can lead to its exceeding if tea intake is higher. Bioavailability of $\mathrm{Ni}$ from tea should be also taken into account, but there is no such data reported. Nickel deficiency has not been observed in humans, whereas exposure to its high levels may result in adverse health effects. High Ni concentration in tea can be due to the application of low-quality fertilizers contaminated with heavy metals that are deposited in soils and tea leaves [17].

\section{Conclusions}

Nowadays, due to the increasing environment contamination, it is important to assess toxic metal and bioelement intake with food, including $\mathrm{Pu}$-erh and fruit teas that consumption steadily increases. In our study, it was found that there is no health hazard associated with exposure to $\mathrm{Cd}$ and $\mathrm{Pb}$ via consumption of both kinds of the analyzed tea. However, if $\mathrm{Ni}$ contamination is observed, its TDI can be exceeded. Such situations can be possible in case of tea bag consumption, which as shown in statistical analysis are described mainly by heavy metals.

It was also concluded that multivariate techniques constitute efficient tools helpful in differentiation of tea samples in view of their quality, type, and confection. Magnesium, $\mathrm{Ca}, \mathrm{K}, \mathrm{Na}, \mathrm{P}, \mathrm{Mn}, \mathrm{Cu}, \mathrm{Fe}, \mathrm{Zn}, \mathrm{Co}, \mathrm{Cr}, \mathrm{Ni}, \mathrm{Cd}$, and $\mathrm{Pb}$ proved to be good descriptors for diversification of the analyzed samples.

Acknowledgments This project was supported by the Ministry of Science and Higher Education of the Republic of Poland, from the quality-promoting subsidy under the Leading National Research Centre (KNOW) program for the years $2012-2017$. 
Open Access This article is distributed under the terms of the Creative Commons Attribution 4.0 International License (http:// creativecommons.org/licenses/by/4.0/), which permits unrestricted use, distribution, and reproduction in any medium, provided you give appropriate credit to the original author(s) and the source, provide a link to the Creative Commons license, and indicate if changes were made.

\section{References}

1. Daglia M, Antiochia R, Sobolev AP, Mannina L (2014) Untargeted and targeted methodologies in the study of tea (Camellia sinensis L.). Food Res Intern 63:275-289

2. Ming T, Zhang W (1996) The evaluation and distribution of genus Camellia. Acta Botan Yunnan 18:1-13

3. Ahmed S, Unachukwu U, Stepp JR, Peters CM, Long C, Kennelly E (2010) Pu-erh tea tasting in Yunnan, China: correlation of drinkers' perceptions to phytochemistry. J Ethnopharmacol 132: $175-185$

4. Stańczyk A (2010) Właściwości zdrowotne herbaty. Bromat Chem Toksykol 4:498-504(in Polish)

5. Heiss ML, Heiss RJ (2007) A cultural history and drinking guide. In: The story of tea. Ten Speed Press, New York

6. Chung F, Schwartz J, Herzog CR, Yang Y (2003) Tea and cancer prevention studies in animals and humans. J Nutr 10:3268-3274

7. Zeyuan D, Bingying T, Xiaolin L, Jinming H, Yifeng C (1998) Effect of green tea and black tea on the metabolisms of mineral elements in old rats. Biol Trace Elem Res 65:75-86

8. Zheng H, Li JL, Li HH, Hu GC, Li HS (2014) Analysis of trace metals and perfluorinated compounds in 43 representative tea products from South China. J Food Sci 6:1123-1129

9. Chen Y, Xu J, Yu M, Chen X, Shi J (2010) Lead contamination in different varieties of tea plant (Camellia sinensis L.) and factors affecting lead bioavailability. J Sci Food Agr 9:1501-1507

10. Kabata-Pendias A, Szteke B (2015) Trace elements in abiotic and biotic environments. CRC Press-Taylor \& Francis Group, Boca Raton

11. Grembecka M, Malinowska E, Szefer P (2010) Differentiation of market coffee and its infusions in view of their mineral composition. Sci Total Environ 383:59-69

12. Official Methods of Analysis of AOAC International Official Method 991.25 (2002) 17th Ed., Rev 1. In: Calcium, magnesium and phosphorus in cheese atomic absorption spectrophotometric and colorimetric method. AOAC International, Gaithersburg, MD, USA

13. Konieczka P, Namiesnik J (2009) Quality assurance and quality control in the analytical chemical laboratory: a practical approach. CRC Press - Taylor \& Francis Group, Boca Raton

14. Szefer $P$ (2007) Chemometric techniques in analytical evaluation of food quality. In: Szefer P, Nriagu JO (eds) Mineral components in foods. CRC Press-Taylor \& Francis Group, Boca Raton

15. McKenzie JS, Jurado JM, Pablos F (2010) Characterisation of tea leaves according to their total mineral content by means of probabilistic neural networks. Food Chem 123:859-864

16. Malik J, Szakova J, Drabek O, Balik J, Kokoska L (2008) Determination of certain micro and macroelements in plant stimulants and their infusions. Food Chem 111:520-525

17. Seenivasan S, Manikandan N, Muraleedharan NN, Selvasundaram R (2008a) Heavy metal content of black teas from South India. Food Control 19:746-749

18. Seenivasan S, Manikandan N, Muraleedharan NN (2008b) Chromium contamination in black tea and its transfer into tea brew. Food Chem 106:1066-1069
19. Cao H, Qiao L, Zhang H, Chenet J (2010) Exposure and risk assessment for aluminium and heavy metals in Pu-erh tea. Sci Total Environ 408:2777-2784

20. Karak T, Bhagat RM (2010) Trace elements in tea leaves, made tea and tea infusion: a review. Food Res Intern 43:2234-2252

21. Lv H, Lin Z, Tan JF, Guo L (2013) Processing and chemical constituents of Pu-erh tea: a review. Food Res Intern 53:938-944

22. Pękal A, Biesaga M, Pyrzynska K (2013) Trace metals and flavonoids in different types of tea. Food Sci Biotech 22:925-926

23. Mehra A, Baker CL (2007) Leaching and bioavailability of aluminium, copper and manganese from tea (Camellia sinensis). Food Chem 100:1456-1453

24. Jonah SA, Williams IS (2000) Nutrient elements of commercial tea from Nigeria by an instrumental neutron activation analysis technique. Sci Total Environ 258:205-208

25. Ashraf W, Mian AM (2008) Levels of selected heavy metals in black tea varieties consumed in Saudi Arabia. Bull Env Cont Toxic 81:101-104

26. Jin CW, He YF, Zhang K, Zhou GD, Shi JL, Zheng SH (2005) Lead contamination in tea leaves and non-edaphic factors affecting it. Chemosphere 61:726-732

27. Dambiec M, Polechonska L, Klink A (2013) Levels of essentials and non-essential elements in black teas commercialized in Poland and their transfer to tea infusion. J Food Compos Anal 31:62-66

28. Wróbel K, Wróbel K, Urbina EMC (2000) Determination of total aluminum, chromium, copper, iron, manganese and nickel and their fractions leached to the infusions of black tea, green tea, Hibiscus sabdariffa and Ilex paraguariensis (mate). Biol Trace Elem Res 78:271-280

29. Moreda-Pineiro A, Fisher A, Hill SJ (2003) The classification of tea according to region of origin using pattern recognition techniques and trace metal data. J Food Compos Anal 16:195-211

30. Fernandez PL, Pablos F, Martin MJ, Gonzalez AG (2002) Multielement analysis of tea beverages by inductively coupled plasma atomic emission spectrometry. Food Chem 76:483-489

31. Herrador MA, Gonzalez AG (2001) Pattern recognition procedures for differentiation of green, black and oolong teas according to their metal content from inductively coupled plasma atomic emission spectrometry. Talanta 53:1249-1257

32. Grembecka M, Szefer P (2013) Comparative assessment of essential and heavy metals in fruits from different geographical origins. Environ Monit Assess 185:9139-9160

33. Jarosz M (2012) Normy żywienia dla populacji polskiej nowelizacja. IŻŻ, Warsaw(in Polish)

34. American recommendations (2011) Food and Nutrition Board. Institute of Medicine, National Academies Press

35. Powell JJ, Trevor JB, Thompson RPH (1998) In vitro mineral availability from digested tea: a rich dietary source of manganese. Analyst 123:1721-1724

36. Mossion A, Potin-Gautier M, Delerue S, Le IH, Behra P (2008) Effect of water composition on aluminium, calcium and organic carbon extraction in tea infusions. Food Chem 106:1467-1475

37. WHO (2010) Seventy-third report of the Joint FAO/WHO Expert Committee on Food Additives. World Health Organization, Geneva. URL http://whqlibdoc.who.int/trs/WHO_TRS_960_eng. pdf. Accessed 2 Jun 2015

38. WHO (2011) Lead in drinking-water, background document for preparation of WHO Guidelines for drinking-water quality. World Health Organization, Geneva. URL http://www.who.int /water sanitation_health/dwq/chemicals/lead.pdf. Accessed 2 Jun 2015

39. Salahinejad M, Aflaki F (2009) Toxic and essential mineral elements content of black tea leaves and their tea infusions consumed in Iran. Biol Trace Elem Res 134:109-117

40. EFSA (2015) Scientific Opinion on the risks to public health related to the presence of nickel in food and drinking water. European Food Safety Authority. URL http://www.efsa.europa.eu /de/efsajournal/ doc/4002.pdf. Accessed 2 Jun 2015 